\title{
MENINGKATKAN KEMAMPUAN MENULIS MAHASISWA DENGAN PENGINTEGRASIAN POWERS DALAM ASESSMEN PORTOFOLIO ELEKTRONIK
}

\author{
Ni L. Pt. Eka Sulistia Dewi \\ Jurusan Pendidikan Bahasa Inggris \\ Universitas Pendidikan Ganesha \\ echaningdharma@yahoo.com
}

\begin{abstract}
Abstrak
Penelitian ini merupakan penelitian tindakan kelas yang bertujuan untuk meningkatkan kemampuan mahasiswa dalam menulis dengan mengaplikasikan Strategi POWERS berbasis portopolio elektronik. Penelitian ini dilakukan berdasarkan hasil observasi awal yang berupa interview dan pre-test yang menunjukkan bahwa kemampuan mahasiswa semester 2B yang berjumlah 29 orang di tahun ajaran 2011/2012 di Jurusan Pendidikan Bahasa Inggris dalam menulis paragraf tersebut masih kurang. Dari segi proses, pada awalnya mahasiswa sangat tergantung pada kehadiran dosen dikelas, kurang percaya diri bahkan cenderung subjektif. Namun setelah diberikan tindakan, kepercayan diri mahasiswa semakin meningkat (lebih mandiri), mereka cenderung lebih objektif, terbuka, jujur dan mampu bekerja sama serta mengambil resiko dengan baik. Dari segi hasil menulis, hasil belaar mahasiswa pun mengalami peningkatan. Hal ini dapat dilihat dari meningkatnya skor individu dan rata-rata pada pre-test 25,67 (cukup), 32,17 (bagus) pada post-test 1 dan 36,69 (sangat bagus) pada post-test 2. Peningkatan kemampuan mahasiswa juga berpengaruh pada nilai akhir mahasiswa diakhir semester dimana rata-rata nilai akhir mahasiswa adalah B.
\end{abstract}

Kata Kunci: menulis, asesmen portopolio, powers

\begin{abstract}
This classroom action-based reseach was intended to improve the 29 students of class $2 \mathrm{~B}$ in English Education Department in the academic year 2011/2012 in writing pargraph through the implementation of POWERS strategy. The reserach was conducted based on the pre-test and intrview conducted to the lecturer of Writing 1 course. The result shows that the students were still dependent on the lecturer's presency in the classroom, having less self confidence in writing, and tend to be subjective. But, after the treaments, the students' acheivement in writing could be improved that can be seen from the result of their post-test in cycle I and II: 25.67 (fair) to 32.17 (good). This improvement also influence the students' final score in that was B.
\end{abstract}

Key words: writing, portfolio, powers

\section{PENDAHULUAN}

Ada beberapa alasan yang dikemukan mengenai pentingnya menulis, walaupun keterampilan ini banyak yang memandang masih sangat sulit. Menurut Hairston sebagaimana dikutip oleh Suadnyani (2009:2), menulis itu penting karena menulis bisa menjadi sarana untuk menemukan sesuatu, memunculkan ide baru, melatih kemampuan mengorganisasikan dan menjernihkan berbagai konsep atau ide, melatih sikap objektif yang ada pada diri seseorang, membantu untuk menyerap dan memproses informasi, serta melatih untuk berfikir aktif. Dengan demikian, jelaslah bahwa menulis sangat bermanfaat, meskipun dibalik itu proses menulis terkesan masih sulit. 
Kesulitan ini pun tampak pada mata kuliah Writing 1 yang merupakan salah satu mata kuliah yang menekankan pada keterampilan menulis. Mata kuliah ini diprogramkan untuk mahasiswa Jurusan Pendidikan Bahasa Inggris, Fakultas Bahasa dan Seni, Universitas Pendidikan Ganesha pada semester II. Sesuai dengan silabus mata kuliah tersebut (The Competency-based Sylabus Development and Assessment System), mata kuliah ini memiliki tujuan umum agar mahasiswa mampu menghasilkan paragaraf-paragraf dalam berbagai pola pengembangan seperti stating reason and examples, opinion, definition, cause and effect, clasification, dan comparison and contrast.

Dari hasil pengamatan terhadap tugas pertama mahasiswa semester IIB di tahun akademik 2011/2012 dalam menulis paragraf yang dikembangkan dengan pengembangan alasan dan contoh (reasons and example), semua mahasiswa tidak dapat menulis kalimat topik dengan benar. Sebagai akibatnya, ide mereka terkesan jump-up atau tidak terorganisasi dengan baik sehingga paparan mereka dalam paragraf yang dihasilkan tidak mudah dipahami. Disamping itu, mahasiswa juga cenderung untuk mengabaikan syarat-syarat mekanik seperti ejaan dan tanda baca yang berakibat pada ketidaksempurnaan hasil karya mereka. Kecerobohan-kecerobohan seperti ini sudah semestinya juga mendapatkan perhatian. Padahal mata kuliah ini merupakan landasan bagi mahasiswa untuk dapat mengambil mata kuliah Writing II dan Writing III, Scientific Writing serta untuk bisa menghasilkan tulisan akademik lainya yang berkualitas.

Dari interview yang dilaksanakan dengan pengampu mata kuliah tersebut didapatkan suatu informasi bahwa dosen bersangkutan bahwa mahasiswa hanya diminta untuk mengkombinasikan kalimatkalimat sesuai dengan topik untuk membentuk sebuah paragaraf, sehingga ketika mahasiswa diminta untuk menghasilkan produknya sendiri, mereka cenderung mengalami kesulitan untuk mengembangkan ide. Disamping itu pula, dari interview yang dilakukan dengan mahasiswa peserta kuliah tersebut diketahui bahwa sebagian besar dari mereka merasa cepat bosan dalam perkuliahan karena mereka diminta melakukan kegiatan yang sama disetiap pertemuan. Mahasiswa cenderung menjadi sangat tergantung pada kehadiran dosen dan sering merasa ragu akan apa yang dikerjakan. Dengan kata lain, kepercayaan diri mereka kurang. Bahkan, banyak mahasiswa yang cenderung menjadi bosan dengan adanya kegiatan-kegiatan yang monoton.

Inteview juga memberikan data tentang metode lain yang sudah pernah diterapkan dalam pengajaran Writing I. Dari interview itu didapatkan informasi bahwa pengasuh telah menggunakan portopolio asesmen dalam pengajaran. Namun, terdapat kelemahan dalam penerapannya yaitu banyak mahasiswa yang tidak mau memanfaatkan kesempatan konsultasi sebaik mungkin untuk membahas permasalahan mereka dalam menulis agar dicarikan pemecahan yang terbaik, serta ada juga mahasiswa yang mengumpulkan tugas tanpa diperbaiki sesuai dengan saran dan komentar yang diberikan sehingga hasilnya jauh dari memuaskan. Dari data tersebut menunjukkan bahwa kemampuan mahasiswa dalam menulis masih kurang.

Temuan yang lain juga didapatkan dilihat dari penerapan pendekatan proses yang dilakukan oleh pengampu. Pendekatan proses tersebut mencakup prewriting, composing, dan revising. Namun dalam penerapannya, pendekatan tersebut tidak dapat diterapkan secara maksimal. Yang dimaksud dengan ketidakmaksimalan pelaksanaan adalah adanya kekurangankekurangan yang disebabkan oleh baik keterbatasan pengasuh maupun mahasiswa itu sendiri. Dalam langkah revising misalnya, yang pada hakikatnya adalah tahap perbaikan tulisan, seringkali mahasiswa malah memasukkan ide-ide baru yang seharusnya muncul pada tahap prewriting. 
Walaupun demikian, untuk memudahkan pemantauan dalam proses pembelajaran dan meminimalkan kesalahan mahasiswa telah diadakan upaya konsultasi (teacherstudents conference) pada tiap akhir tahapan. Pada saat itu dosen memberikan bimbingan baik berupa saran maupun komentar perbaikan. Namun karena keterbatasan waktu, sering kali mahasiswa mengabaikan saran yang diberikan dan tidak melakukan perbaikan sehingga akhirnya tugas mahasiswa dikumpulkan untuk dinilai walaupun dengan hasil yang tidak maksimal. Ada juga mahasiswa yang sering kali tidak melakukan pengarsipan dengan baik sehingga catatan yang dimiliki sangat sulit untuk ditemukan kembali. Hal ini berpengaruh pada produk yang dihasilkan.

Dari paparan diatas dapat dipahami bahwa pendekatan yang telah digunakan dalam mengasuh mata kuliah tersebut memiliki kelemahan dan keunggulan. Keunggulannya yaitu pendekatan proses tersebut telah terbukti efektif dimana mahasiswa telah berhasil menghasilkan suatu produk berupa tulisan walaupun hasil yang diperoleh tidak maksimal. Sedangkan kelemahannya yaitu: (1) belum dapat mengoptimalkan kemampuan menulis mahasiswa, (2) tingkat ketergantungan mahasiswa yang masih sangat tinggi dengan kehadiran dosen dalam menyelesaikan tugasnya atau dengan kata lain belum mandiri, (3) kurang efektifnya proses konsultasi karena konsultasi itu sendiri memerlukan waktu yang lama dan bersifat indifidual, sedangkan dosen mengalami kesulitan dalam membagi waktu karena tugas mengajar yang lain masih menunggu., (4) pendokumentasian yang kurang baik menghambat proses penemuan kembali produk yang dihasilkan.

Mengingat kelemahan itulah dipandang perlu suatu upaya untuk perbaikan pembelajaran mata kuliah Writing I untuk meningkatkan kemampuan menulis mahasiswa semester dua sesuai dengan karakteristik mata kuliah itu sendiri yang menekankan pada kemampuan dasar menulis yang mencakup penguasaan grammar, tanda baca, ejaan yang tepat, penulisan dan pengembangan ide pokok, pemilihan kata yang tepat dan memiliki kemapuan dalam membuat draft, memperbaiki dan mengedit tulisan. Selain itu mahasiswa juga diharapkan mampu memahami elemen-elemen paragraf serta karakteristik paragraf yang bagus. Lebih jauh lagi, mahasiswa yang mengambil mata kuliah tersebut diharapkan mampu menghasilkan produk berupa paragrafparagraff yang padu dengan berbagai pola pengembangan. Disamping itu pula, secara implisit diharapkan bahwa mahasiswa mampu meningkatkan kepercayaan diri serta bisa merefleksi diri sendiri untuk mengetahui apa yang menjadi kelemahan dan kelebihan mereka mereka dalam menulis.

Oleh karena itu, dalam pembelajaran Writing I sangat penting untuk diupayakan perbaikan dalam proses belajar dan mengajar dengan menimbangkan halhal berikut: (1) mengurangi ketergantungan mahasiswa terhadap dosen sehingga mahasiswa menjadi mandiri dan aktif, (2) perlu dilakukan pemantauan proses perbaikan tulisan secara sistematis dimana pemantauan tersebut dapat menjamin kualitas produk, (3) perlu adanya bukti-bukti dari proses maupun hasil belajar tersebut yang tersimpan rapi dan mudah untuk ditemukan kembali. Untuk itu diperlukan model pembelajaran yang terpadu antara kegiatan belajar mengajar dengan asesmen yang digunakan dimana dalam asesmen tersebut harus terdapat suatu umpan balik yang efektif, baik dalam hasil maupun tanggung jawab mahasiswa. Hal ini dapat dilakukan melalui pengaplikasian asesmen portopolio elektronik yang padu dengan pendekatan proses yang digunakan.

Portopolio adalah prosedur pengumpulan informasi secara formal menggunakan kriteria tertentu yaitu sample karya, evaluasi diri dan kriteria penilaian penilaian (O'Malley dan Valdez $\mathrm{P}$ dalam Marhaeni, 2005). Dengan adanya evaluasi 
diri ini diharapkan kemampuan mahasiswa untuk mengoreksi diri mereka dalam merespon komentar dalam tulisan mereka yang terkumpul dalam folder bisa ditingkatkan sehingga berdampak pada meningkatnya kepercayaan diri dan kemandirian mereka dalam menulis dengan Bahasa Inggris. Disamping itu, waktu akan dapat dimanfaatkan seefektif mungkin dan mahasiswa akan menjadi tahu akan kelemahan dan kelebihan mereka sendiri dalam menulis serta mereka akan belajar untuk jujur pada diri mereka sendiri dan juga pada teman dan dosen karena mau tidak mau mahasiswa harus memperbaiki tulisan mereka berdasarkan catatan yang ada pada teacher-students conference dan peer evaluation dalam membahas paragrafparagraf yang mereka telah hasilkan. Penggunaan media elektronik juga akan membantu mahsiswa untuk menemukan kembali produk yang dihasilkan dengan lebih mudah.

Sementara itu, sehubungan dengan kendala-kendala yang dihadapi dalam proses menulis yang akan diterapkan, strategi POWERS merupakan strategi alternatif yang bisa menjadi pemecah masalah. Dengan demikian, karya mahasiswa tidak hanya dikoleksi dalam bentuk tulisan di atas kertas namun akan ada suatu pembahasan yang dilakukan dengan bantuan elektronik dalam proses menulisnya yaitu dengan media jejaring sosial Facebook. Dimana mahasiwa bisa saling memeberikan feedback terhadap karya mahasiswa dengan cara yang menyenangkan serta mahasiswa juga akan dihadapkan pada pembaca yang "nyata".

Penerapan portofolio sebagai sarana dalam assessmen kemampuan menulis sudah menjadi bahan dari beberapa peneliti. Penelitian yang dilakukan oleh Alan Hirvela dan Yuerong Liu Sweetland yang tertuang dalam jurnal pendidkan Elsevier (2010) menyatakan bahwa para subjek penelitian merasakan penerapan portofolio dalam menulis sangat membantu mereka untuk mengasilkan tulisan yang baik. Yang terpenting adalah, para subjek penelitian dapat menghasilkan karya yang meaningful. Hasil penelitian yang lain dalam penerapan portofolio ini juga dilakukan oleh Dewi pada tahun 2007 dan 2008. Dalam penelitian tersebut dua jenis portofolio, paper-based dan electronic portfolio, diaplikasikan pada mata kuliah Writing I dan Writing II. Kedua penelitian tersebut menunjukan bahwa secara umum portofolio bisa membantu mahasiswa untuk meningkatkan kemampuan menulis mereka. Kehadiran elektronik dalam tahapan menulis juga memberikan pengaruh pada kemampuan dan motivasi mahasiswa.

Mengingat menulis adalah suatu proses maka ada tahapan-tahapan yang hendaknya dilalui seperti yang ditawarkan oleh strategi POWERS: pre-write (pra penulisan), organize (pengorganisasian), Write (Penulisan), Edit (Pengeditan), Revise (Perbaikan) dan Share (Pempublikasian). Berbeda dengan pempublikasian yang sering dilakukan dalam menulis, seperti hanya dengan membaca di kelas dan menampilkan karya mahasiswa di majalah dinding, dalam penelitian ini akan menggunakan media pempublikasian lewat media internet yaitu Facebook.

Internet, khususnya media Facebook sebagai salah satu bentuk jejaring sosial yang masih menjadi trend dewasa ini telah mampu memberikan dampak positif pada kemampuan menulis mahasiswa. Dari penelitian yang dilakukan oleh Djiwandono dan hasilnya disampaikan dalam LIA Reseach Colloquium 2009, diketahui bahwa pengunaan media Facebook dalam kelas Writing // dapat meningkatkan kemampuan menulis dan motivasi mahasiswa di Jurusan Pendidikan Bahasa Inggris di Universitas Negeri Malang. Dengan demikian, media Facebook ini akan sangat bermanfaat apabila diterapkan dalam tahapan proses menulis menggunaan strategi POWERS.

Hasil penilitian dengan pengunaan media internet yang lainnya juga telah dinyatakan oleh Desiani Natalina Muliasari dalam Jurnal Educationist (2010). Desiani 
menjelaskan pemanfaatan internet sebagai alat bantu untuk meningkatkan kemampuan menulis mahasiswa ITB dalam Academic Writing terbukti efektif untuk meningkatkan keantusiasan mahasiswa dalam menulis karena mereka dihadapkan pada pembaca yang "nyata", dan juga keterampilan mereka, dimana mahasiswa tidak lagi menulis degan organisasi yang tidak jelas, bahkan mereka cenderung untuk menulis lebih banyak dibandingkan sebelumnya. Bagi pengajar, penggunaan media internet ini bisa menghindarkan mereka dari kekhawatiran akan kehilangan tulisan mahasiswa yang ditulis di atas kertas akibat dari kecerobohan penyimpanan.

Secara spesifik, penelitian dalam penerapan strategi POWERS dalam meningkatkan kemampuan menulis mahasiswa belum dapat ditemukan. Namun strategi ini banyak digunakan di sekolah menengah, seperti dari hasil penelitian yang dilakukan oleh Suarsini pada tahun 2007 yang menerapkan stratei POWERS untuk meningkatkan kemampuan menulis sisswa di SMA Negeri 3 Singaraja. Hasilnya adalah mahasiswa mampu meningkatkan kemampuan menulis mereka, terutama dalam menulis paragaraf naratif. Pada tahun 2010, Widiary melakukan penelitian eksperimen untuk mengetahui pengaruh POWERS terhadap kemampuan menulis mahasiswa kelas 8 di SMP Negeri 2 Singaraja. Hasilnya adalah POWERS memiliki pengaruh yang signifikan terhadap kemampuan menulis mahasiswa dibandingkan dengan strategi konvensional yang digunakan oleh guru.

$\begin{array}{ll}\text { Dengan demikian, } & \text { starteg } \\ \text { POWERS diharapkan akan mampu } \\ \text { meningkatkan kemampuan menulis }\end{array}$
mahasiswa semester II yang mengambil mata kuliah Writing I di Jurusan Pendidikan Bahasa Inggris Fakultas Bahasa dan Seni Universitas Pendidikan Ganesha ditahun akademik 2011/2012. Diharapkan mahasiswa dapat megikuti langkah-langkah menulis yang baik sehingga dapat menghasilkan tulisan yang berkualitas yang ditunjukkan dengan prestasi belajar mereka, dan pengajar akan memperoleh gambaran dan masukan untuk dapat dijadikan pertimbangan dalam menentukan alat penilaian dan strategi pengajaran dalam kelas menulis, terutama dalam menulis paragraf dengan berbagai pola pengembangan.

\section{METODE}

Untuk dapat mengetahui hasil dari pengaplikasian strategi ini untuk meningkatkan kemampuan menulis mahasiswa maka penelitian tindakan kelas ini melibatkan 29 subjek penelitian (kelas IIB) di jurusan Pendidikan Bahasa Inggris semester dua tahun akademik 2011/2012. Sedangkan objek penelitian ini adalah hasil tulisan mahasiswa serta proses menulis mahasiswa itu sendiri.

Ada enam instrumen yang digunakan untuk mengumpulkan data, yang dibedakan dalam instrument yang digunakan untuk menilai proses belajar dan hasil belajar. Instrument yang digunakan untuk menilai proses belajar yaitu interview guide, Portfolio Folder, Self-evaluation checklist, tacher's diary dan Instrument yang digunakan untuk menilai hasil belajar adalah writing test dan evaluation rubric.

Penelitian ini dilaksankaan dalam dua siklus dimana masing-masing siklus mengandung proses planning (penyiapan instrument), action (pengaplikasian persiapan), observation (observasi terhadap penggunaan strategi pengajaran dan observasi terhadap kemapuan mahasiswa), and reflection (menganalisa data yang telah dikumpulkan dan mengambil kesimpulan apakah cycle akan dilanjutkan atau sudah dianggap sukses (Kemmis and McTaggart, 1988:14).

Data yang telah dikumpulkan dibedakan menjadi data kualitatif dan kuantitatif. Kuantitatif data diperoleh dari hasil test yang dilakukan sebelum penelitian berlangsung dan setelah tiap cycle berakhir. Sedangkan data kualitatif didapatkan dari hasil observasi selama proses belajar 
mengajar dan refleksi mahasiswa yang ditulis dalam setiap akhir tugas portopolio.

\section{HASIL DAN PEMBAHASAN}

Kemampuan mahasiswa dalam mengembangkan paragraf naratif dan deskriptif dalam pretest seimbang. Hal ini dapat dilihat dari nilai rata-rata mahasiswa disetiap indikator yang sebarannya hanya berbeda pada isi. Dimana kemampuan mahasiswa untuk mengembangkan paragraf naratif lebih bagus dari pada paragraf deskriptif. Namun secara keseluruhan, kemampuan menulis mahasiswa masih rendah terlihat dari nilai rata-rata mereka yang masih rendah yaitu 25,72 $(=58,46$ setelah dikompen) untuk naratif dan 25,62 $(=58,23$ setelah dikompen) untuk deskriptif.

Dari intrview yang dilakukan setelah pemberian pre-test, didapatkan informasi bahwa mahasiswa mengalami kesulitan untuk menghasilkan produk yang baik karena mereka mengalami kesulitan dalam proses menulis. Sebagian besar mahasiswa mengungkapkan bahwa mereka memliki banyak ide yang kan dituangkan namun ketika mereka menyelesaikan satu kalimat mereka melupakan ide awal yang ingin mereka tuliskan. Memang semua mahasiswa langsung menulis tanpa membuat outline maupun draft. Pada saat mulai menulis mereka hanya bengong mencoba mencari ide tanpa mau mencobacoba menungkannya dalam sebuah kerangka tulisan. Disamping itu pula, ada yang mengatakan bahwa mereka merasa tertekan untuk menyelesaikan paragraf mereka hanya dalam waktu yang singkat. Mereka memerlukan lebih banyak waktu untuk menulis sekaligus memperbaikinya. Mereka tidak memiliki kesempatan unutuk mengedit tulsan mereka. Selanjutnya, mahasiswa enggan membagi permasalahan mereka dengan teman maupun peneliti. Mereka cenderung menyimpan kesulitan mereka. Dengan kata lain, mahasiswa cenderung unutk tertutup dan hanya memberikan informasi ketika ditanyai. Hal ini menimbulkan kendala untuk mengetahui dimana sebenarnya letak kesulitan mereka.

Berdasarkan hasil interview dan analisa hasil tulisan mereka, maka penelti pun mengambil kesimpulan bahwa kemampuan mahasiswa dalam menulis paragraf naratif dan deskriptif perlu ditingkatkan karena akan berpengaruh pada hasil menulis mereka dalam pengembangan yang berbeda dan tentunya berpengaruh pada kemampuan menulis untuk tulisan akdemik yang lainnya. Disamping itu, mahaasiswa juga perlu diarahkan pada proses nelajar yang mandiri dan terbuka serta mampu berbagi dan bekerja sama. Sehingga, sebagai solusi permasalahan tersebut dirancanglah sebuah treatment yang diimplementasikan pada siklus I dengan harapan kemampuan mahasiswa dalm mengahsilkan produk dengan proses yang baik dapat ditingkatkan.

Dari penerapan evaluasi diri pada siklus I, kemampuan mahasiswa dikategorikan bagus. Jika dilihat lebih rinci, $12(41,37 \%)$ mahasiswa telah mampu mengunakan checklist dengan rata-rata Excelent (Baik sekali), 15 (51,72\%) mahasiswa menggunakannya dengan baik dan hanya 2 (6.89\%) yang menggunakan dengan rata-rata cukup. Pada optional paragraph ada 5 mahasiswa yang mampu mengunkan deskriptor dengan sempurna $(100 \%)$. Ini berarti mahasiswa mau mempelajarkan diri mereka. Mau menggali kemampuan masing-masing dan bekerja keras dengan mandiri untuk hasil yang maksimal.

Selanjutnya, dari analisa evaluasi diri yang diberikan pada mahasiswa terlihat bahwa tingkat kemandirian mahasiswa untuk bekerja semakin meningkat. Pada siklus pargraf utama, kemampuan mahasiswa untuk mengunakan evaluasi diri dalam mengembangkan paragraph naratif masih kurang, tetapi pada optional paragrap, permasalahan terlihat dapat lebih diatasi karena mereka belajar dari apa yang mereka lakukan pada pembuatan paragraf utama. 
Dari interview yang dilakukan dengan mahasiswa dalam class conference didapatkan informasi bahwa mahasiswa belum mengerti benar bagaimana cara mengisi evaluasi diri tersebut dan adanya descriptor yang mereka belum paham. Disamping itu pula,mahasiswa bahkan tidak percaya pada dirinya bahwa ada hal yang bagus dalam diri mereka dalam menulis. Mereka cenderung putus asa sebelum memulai tulisannya sehingga penyelesaiannya menjadi sangat lambat. Disamping itu pula, mereka cenderung untuk malas untuk mengembangkan ide sehingga tulisan menjadi tidak menarik untuk dibaca. Budaya yang berkembang di negara sedang berkembang tidak terbiasa memuji diri sendiri juga berpengaruh. Mahasiswa cenderung enggan untuk memberi skor terbaik untuk dirinya sendiri namun cenderung untuk bertindak subjektif ketika memeriksa pekerjaan teman. Mahasiswa masih juga merasa malu untuk menuliskan permasalahan mereka di group begitu juga untuk mendatangi pengampu mata kuliah untuk berkonsultasi secara langsung. Mereka hanya menunggu saat dimana bisa bertemu dikelas. Hal ini sangat menghambat dan merugikan karena tiap mahasiswa memiliki masalah yang berbeda-beda dan memerlukan waktu yang banyak untuk menyelesaikannya, 100 menit pertemuan dikelas tidaklah cukup untuk membahasnya. Pemberian masukan lewat revisi diatas kertas juga kurang efektif karena mahasiswa cenderung untuk memperbaiki bagian yang diberi tanda saja tanpa melakukan perubahan secara general. Ruang kosong yang terdapat pada lembar kerja mahasiswa juga menyulitkan peneliti untuk memberikan komentar, lagipula, komentar yang panjang memerlukan waktu yang lama untuk ditulis.

$$
\text { Untuk }
$$

menanggulangi

permasalahan ini, peneliti mengunakan sesi clas-conference di group dengan harapan setiap mahasiswa dapat membagi pengalaman dengan teman yang lain. Tiap mahasiswa diberikan kebebasan untuk mengemukakan permasalahan dan memberikan tanggapan atas permasalahan tersebut. Namun factor budaya kembali menjadi kendala. Mahasiswa cenderung malu untuk mengungkapkan pemasalahn mereka, bahkan untuk memberikan solusi pun mereka enggan karena mereka menganggap apabila teman diberikan solusi berarti kemampuan mereka akan tersaingi.

Untuk itu, pada siklus ke-dua, sesi class conference ditambah dengan teacherstudents conference, dimana mahasiswa benar-benar dibebaskan untuk bekerja di luar kelas dan menemui pengampu ketika akan membahas suatu kendala yang mahasiswa hadapi dengan membawa alat bantu elektronik untuk merekam conference tersebut. Jadi ketika mahasiswa datang untuk berkonsultasi, mahasiswa membawa portopolio mereka dan merekam semua percakapan yang berlangsung dengan menggunakan media elektronik yang mereka miliki. Disamping itu pula, peneliti juga mempublikasikan point-point yang menjadi permasalahan di group untuk dapat dikadikanmasukan kepada mahasiswa yang lain.

Dari analisis terhadap Kemampuan Menulis diketahui bahwa setiap komponen dalam penulisan paragraf naratif setelah diberikan tindakan mengalami peningkatan. Begitu pula pada rata-rata akhirnya. Pada pre-test, rata-rata mahsiswa dikategorikan cukup, namun setelah tindakan meningkat menjadi baik. 7 orang (24,14\%) mahasiswa mendapatkan nilai sangat bagus dan sisanya, 22 orang $(75,86 \%)$ mendapatkan nilai bagus. Kemampuan mahasiswa ini meningkat $11 \%$ dibanding dengan nilai pretest.

Seperti halnya pada penggunaan checklist, kemampuan mahasiswa mengalami peningkatan dilihat dari hasil menulisnya. Rata-rata pengunaan checklist berbanding lurus dengan hasil menulis paragraf mahasiswa. Mahasiswa yang mengumpulkan nilai baik pada checklistnya menghasilkan nilai yang bagus pula dalam tulisannya. 
Dari interview yang dilakukan dengan mahasiswa didapatkan informasi bahwa pPeningkatan prestasi mahasiswa baik dari segi rata-rata maupun skor individu banyak dipengaruhi oleh pembuatan outline, peggunaan alat bantu berupa gambar dan evaluasi diri. Gambar/foto dinyatakan dapat membantu mereka mengingat kembali kejadian/gambaran yang ingin mereka tulis. Untuk masalah kosa-kata, mahasiswa dibantu dengan menggunakan EnglishEnglish dictionary dan juga dengan melakukan pair-review untuk mendapatkan masukan dari teman sejawat. Mahasiswa juga meminta bantuan mahasiswa yang duduk disemester yang lebih tinggi untuk membantu memberikan masukan atas pilihan kata. Yang tidak kalah pentingnya adalah kelengkapan folder fortopolio mahasiswa. Secara keseluruhan, 100\% mahasiswa telah memenuhi sarat dimana folder mereka lengkap

Dari hasil analisa proses dan hasil belajar mahasiswa di siklus I maka dapat disimpulkan bahwa evaluasi diri dapat membantu mahasiswa untuk menghasilkan produk yang baik. Untuk itu, evaluasi diri tetap digunakan untuk membantu mahasiswa dalam menulis. Begitu pula dengan gambar dan outline. Mahasiswa merasa dangat terbantu sehingga kedua media tersebut juga tetap dimanfaatkan. Namun ada satu hal yang perlu ditambahkan yaitu dalam confference. Pada siklus I, mahasiswa menyatakan bahwa mereka memiliki permasalahan yang berbeda-beda sehingga diperlukan waktu untuk melakukan conference secara individu dan komentar yang ditulis oleh peneliti diatas kertas kerja mereka tidak dapat dimanfaatkan secara maksimal karena komentar terbatas dan ketika diberitahu mahasiswa cenderung melupakan apa yang telah diberitahu.

Untuk itu, pada siklus ke-dua, class conference ditambah dengan teacherstudents conference, dimana mahasiswa benar-benar dibebaskan untuk bekerja di luar kelas dan menemui pengampu ketika akan membahas suatu kendala yang mahasiswa hadapi dengan membawa alat bantu elektronik untuk merekam conference tersebut. Jadi ketika mahasiswa datang untuk berkonsultasi, mahasiswa membawa portopolio mereka dan merekam semua percakapan yang berlangsung dengan menggunakan media elektronik yang mereka miliki. Disamping itu pula, peneliti juga mempublikasi point point penting ringkasan hasil student-teacher conference ke dalam group untuk bisa diperhatikan oleh mahasiswa sebagai bahan perbaikan.

Dari analisa pengunaan evaluasi diri pada siklus II diperoleh data bahwa rata-rata mahasiswa adalah 4 yang dikategorikan bagus. Jika dilihat lebih rinci, 20 (68,96\%) mahasiswa mahasiswa telah mampu mengunakan checklist dengan rata-rata Excelent (Baik sekali), hanaya 9 (31,03\%) mahasiswa menggunakannya dengan baik. Pada optional paragraph ada 8 mahasiswa yang mampu mengunkan deskriptor dengan sempurna (100\%). Ini berarti mahasiswa mau mempelajarkan diri mereka. Mau menggali kemampuan masing-masing dan bekerja keras dengan mandiri untuk hasil yang maksimal.

Selanjutnya, dari analisa evaluasi diri yang diberikan pada mahasiswa terlihat bahwa tingkat kemandirian mahasiswa untuk bekerja semakin meningkat. Pada siklus parahrap naratif rata-rata kemampuan mahasiswa bagus. Namun pada siklus kedua ini, kemampuan mahasiswa untuk mengunakan evaluasi diri dalam mengembangkan paragraph deskriptif menjadi bagus sekali.

Dari interview yang dilakukan dengan mahasiswa dalam class conference dan teacher-students conference didapatkan informasi bahwa mahasiswa sudah menegrti bagaimana mengisi evaluasi diri dan mereka paham betul indikator yang tersedia karena mereka telah belajar dari pengalaman mereka dalam mengerjakan paragraf naratif. Disamping itu pula,mahasiswa menjadi lebih percaya diri dan mampu menghargai pendapat teman dan belajar lebih objektif 
dan mandiri dengan memahami komentar diatas kertas dan komentar dari rekaman.

Dari hasil analisis terhadap
kemampuan menulis, kemampuan mahasiswa meningkat menjadi sangat baik. Hanya 5 mahasiswa yang mendapat nilai bagus dan sisanya 22 mahasiswa mendapatkan nilai sangat bagus. Ini berarti bahwa $75,86 \%$ mahasiswa mampu mencapai nilai maksimal. Kemampuan mahasiswa ini meningkat $8,36 \%$ dibanding dengan nilai pre-test.

Seperti halnya pada penggunaan checklist, kemampuan mahasiswa mengalami peningkatan dilihat dari hasil menulisnya. Rata-rata pengunaan checklist berbanding lurus dengan hasil menulis paragraf mahasiswa. Mahasiswa yang mengumpulkan nilai baik pada checklistnya menghasilkan nilai yang bagus pula dalam tulisannya.

Dari interview yang dilakukan dengan mahasiswa didapatkan informasi bahwa peningkatan prestasi mahasiswa baik dari segi rata-rata maupun skor individu banyak dipengaruhi oleh pembuatan outline, peggunaan alat bantu berupa gambar dan evaluasi diri. Gambar/foto dinyatakan dapat membantu mereka mengingat kembali kejadian/gambaran yang ingin mereka tulis. Untuk masalah kosa-kata, mahasiswa dibantu dengan menggunakan EnglishEnglish dictionary dan juga dengan melakukan pair-review untuk mendapatkan masukan dari teman sejawat. Mahasiswa juga meminta bantuan mahasiswa yang duduk disemester yang lebih tinggi untuk membantu memberikan masukan atas pilihan kata. Penerapan teacher-student conference juga dianggap memberikan kontribusi yang besar karena dengan pembahasan proses dan hasil belajarnya. Mahasiswa mengatakan bahwa dengan melihat dan mendengarkan lagi hasil konferensi dapat membantu mereka memperbaiki kesalahan dan mengevaluasi diri mereka sendiri. Yang tidak kalah pentingnya adalah kelengkapan folder fortopolio mahasiswa. Secara keseluruhan,
$100 \%$ mahasiswa telah memenuhi sarat dimana folder mereka lengkap

\section{KESIMPULAN}

Berdasarkan hasil analisis data dan pembahasan yang telah dilakukan, dapat disimpulkan sebagai berikut. Penggunaan evaluasi diri berbasis portopolio elektronik dapat meningkatkan kemampuan mahasiswa dalam proses menulis paragraf naratif dan deskriptif. Mahasiswa menjadi lebih terbuka, objektif dan tentunya mandiri. Mahasiswa dapat memanfaatkan waktu dengan baik, mereka tidak hanya tergantung pada pertemuan dikelas tetapi juga mereka memanfatkan sela waktu untuk berdiskusi baik dengan teman maupun peneliti untuk memperbaiki produk mereka dengan memanfaatkan group pada jejaring sosial Facebook. Peningkatan afektif ini berlaku sama pada kedua siklusnya. Bahkan pada siklus ke dua dimana mahasiswa diminta untuk menulis paragraf deskriptif, kemampuan mahasiswa untuk menggunakan evaluasi diri sangat meningkat. Begitu pula pada folder fortopolio mereka, mahasiswa mengumpulkannya dengan kengkap. Ini berarti, mahasiswa terlatih untuk disiplin. Conference yang disertai dengan penggunaan alat rekam (elektronik) dirasakan sangat membantu oleh mahasiswa dan mereka berharap dapat mengunakan media yang sama untuk menghasilkan produk selanjutnya.

Dari segi hasil, kemampuan mahasiswa terus meningkat. Dari pre-test menuju post-test, kemampuan mahasiswa terus meningkat. Walaupun pada awalnya mahasiswa masih bingung karena kurang jelasnya indicator yang mereka temui, damun seiring dengan pengalaman mereka dari hari kehari kemampuan mereka dalam memahami indicator dalam evaluasi diripun semakin baik sehingga berpengaruh pada hasil tulisan mereka. Hal ini dapat dapat dilihat dari meningkatnya skor individu dan rata-rata pada pre-test 25,67 (cukup), 32,17 (bagus) pada post-test 1 dan 36,69 (sangat 
bagus) pada post-test 2. Kemampuan mahasiswa pada penulisan paragraf deskriptif lebih baik daripada paragraf naratif karena mahasiswa dapat belajar dari pengalaman mereka pada pembuatan pararaf naratif yang siklusnya dimulai lebih dulu. Peningkatan kemampuan mahasiswa dalam kedua pengembangan paragraf ini juga berpengaruh pada nilai akhir mahasiswa diakhir semester dimana ratarata nilai akhir mahasiswa adalah $\mathrm{B}$.

\section{DAFTAR PUSTAKA}

Bullock and Hawk. 2005. Developing a Teaching Portopolio. Pearson, Merill Prentice Hall

Barret, H.C. 2006. Digital Stories in ePortfolios: Multiple Purposes and Tools. http:www.storycenter.org

Depdiknas, Undiksha. 2006. Pedoman Studi Fakultas Pendidikan Bahasa dan Seni Universitas Pendidikan Ganesha

Djiwandono, P. I. 2009. Using Facebook to Enhance Vocabulary Learning. Proceeding of the 3rd LIA Research Colloquium (pp. 205-211), Yogyakarta, June 25-26.

Glossary Plasmalink. 20002 Available ate www.glossaryplasmalink.com

Hirvela, A. And Swetland, Y. L. Two case studies of $L 2$ writers' experiences across learningdirected portfolio contexts. Available at Elsevier Journal on Teaching Writing 10 Tahun 2010 page 192213. Tersedia Online di www.sciencecredits.com.

Ni Luh Putu Eka Sulistia Dewi. 2007. Evaluasi Diri Berbasis Kombinasi Traditional Paper-based dan Electronic Portfolio untuk Meningkatkan Kemampuan Menulis Mahasiswa. Laporan Penelitian.
Ni Luh Putu Eka Sulistia Dewi. 2008. Startegi Belajar dengan Evaluasi Diri Berbasis Electronic Portfolio untuk Meningkatkan Kemampuan Menulis Mahasiswa. Laporan Penelitian.

Ni Luh Putu Eka Sulistia Dewi. 2008. Evaluasi Diri Berbasis Assessmen Portopolio untuk Meningkatkan Keterampilan Menulis Siswa Kelas XI IPA SMA Laboratorium Undiksha. Laporan Penelitian.

Kemmis, S. dan McTaggart, R. 1988. The Action Research Planner. Vitoria: Deakin University.

Kemp, J \& Toperoff, D. 1998. Guidelines for Portfolio Assessment in Learning English. Available at (kempj@netvision.net.il) and (mailto:debby01@attglobal.net).

Leniadi, M. 2004. The Use of Diary Writing to Improve the Students' Ability in Writing a Narrative Paragrafh. Unpublished Thesis: IKIP N Singaraja.

Marhaeni, Ramendra \& Suwastini. 2005. Optimalisasi Kegiatan Evaluasi Diri Dalam Pembelajaran Berbasis Portofolio untuk Meningkatkan Kemampuan menulis dalam Bahasa Inggris. Singaraja. IKIP N Singaraja.

Muliasari, D. N. The Internet as an Aid in DevelopingWriting Skills.

Available at Jurnal Educationist Vol. IV No. 1 - Januari 2010 page 216

Oshima, A \& Hogue, A. 1988. introduction to Academic Writing. Wesly Publishing Company.

Rolheiser, C \& Ross, J.A. 2000. Student Self-evaluation:What Research Says and What Practice shows. Available at http://www.cdl.org/resourcelibrary/ar ticles/self eval.php 
Suadnyani, Ni Wayan. 2009. Penerapan Strategi POWERS untuk Meningkatkan Keterampilan Menulis Argumentasi Mahasiswa Kelas X.A SMA Negeri 1 Kubutambahan. Skripsi (tidak diterbitkan). Singaraja: Universitas Pendidikan Ganesha

Trisna. 2006. "Using Self-Evaluation Activity in A Portfolio-Based Instruction to Improve the Students' Ability in Writing (A Classroom-Based Action Research Conducted at Class XI.IPA of SMA Laboratorium IKIP N Singaraja in the Academic Year
2005/2006)". Unpublished Thesis: IKIP N Singaraja.

Widiary, L.E.A. 2010. An experimental study on the effect of POWERS strategy upon the $8^{\text {th }}$ Grade students' writing achievement of SMP Negeri 2 singaraja in the academic year 2009/2010. Skripsi (tidak diterbitkan). Singaraja: Universitas Pendidikan Ganesha.

Young, C. 1998. The POWERS Strategy. the students' Guide to the wrting Process. Available on http://www.edwebsdu.edu/wequest/ $\mathrm{htm}$ 